\title{
Intestinal Obstruction from an Adhesion Band Mimicking Peritonitis due to a Complicated Induced Unsafe Abortion: A Case Report
}

\author{
Ibekwe Perpetus Chudi, *Egwuatu, Vincent, **Okidi, Okey
}

\begin{abstract}
Miss E.N. a 19-year old nullipara presented at the Accidents and Emergency unit of the Ebonyi State University Teaching Hospital (EBSUTH), Abakaliki on the 17/5/06 with symptoms and signs of peritonitis from possible uterine and bowel perforation secondary to induced unsafe abortion. At surgery, it was discovered that her problem was due to mechanical small bowel obstruction from adhesion band following appendicectomy two years previously. The case highlights the similarities of its presentation to some of the complications of induced unsafe abortion. (AfrJ Reprod Health 2007; 11[2]:104-107).
\end{abstract}

\section{RÉsumé}

Occlusion intestinale à partir d'une bande d'adhésion de la péritonite mimétique dû à un avortement dangereux provoqué et compliqué: Un rapport de cas ademoiselle E.N. une nullipare, âgée de 19 ans s'est présentée aux services des Accidents et des Urgences du Centre Hospitalier Universitaire de l'état d'Ebonyi (EBSUTH), Abakaliki, le 17 mai 2006 avec des symptômes et des indices de la péritonite causée probablement par à la perforation utérine et intestinale secondaire à l'avortement dangereux provoqué. Au cours de l'opération chirurgicale, il a été découvert que son problème a été causé par une petite occlusion intestinale de la bande d'adhésion suite à une appendicectomie deux ans avant. Le cas met l'accent sur les similarités de la présentation aux certaines complications de l'avortement dangereux provoqué. (Rev Afr Santé Reprod 2007; 11[2]:104-107).

\footnotetext{
KEY WORDS: Intestinal obstruction, induced unsafe abortion, post operative adhesion band, peritonitis

*Department of Obstetrics/Gynaecology **Department of Surgery Ebonyi State University Teaching Hospital Abakaliki, Ebonyi State.
}

Correspondence: Dr. Ibekwe, PC P.O. Box 1019, Abakaliki (480001) Ebonyi State Email: drogoperps@yahoo.com. 


\section{Introduction}

Injury to a viscus during induced abortion is a common occurrence especially in the hands of the untrained, and they abound in our environment. This injury may go unrecognized particularly after a fine penetrating injury by instruments. This unrecognized injury may become apparent after 72 hours with nausea, anorexia, lower abdominal pains and fever, progressing to vomiting, peritonitis and ileus ${ }^{1}$. Induced abortion with uterine perforation and injury to visceral organs are known to be associated with this typical clinical picture. However, intestinal obstructions from adhesions following previous surgeries may share the same clinical evolution of symptoms and signs ${ }^{2}$. In this report, we present a mechanical intestinal obstruction caused by a band of adhesion from previous surgery, mimicking perforated viscus from induced unsafe abortion.

\section{Case Report}

Miss E.N., a 19-year old secondary school student, who was single and nulliparous, presented at the Accidents and Emergency Unit of the Ebonyi State University Teaching Hospital (EBSUTH), Abakaliki on the 17/5/06 with complaints of colicky lower abdominal pains, nausea and vomiting of 4days duration and fever of two days duration. She was unable to pass stool since the onset of symptoms but passed flatus. She also noticed that her abdomen was distending slowly.

Five days prior to the onset of these problems, the patient had terminated an eightweek old unwanted pregnancy at a patent medicine dealer's shop in her village. She was awake during the procedure and disclosed that the man inserted some metallic instruments into her womb.

She had appendicectomy done in a private hospital in 2004 and there was no complication.

On examination, she was ill looking, rather anxious, febrile to touch and pale. The pulse rate was 92 beats per minute and blood pressure was $110 / 70 \mathrm{mmHg}$. The chest was clinically clear and heart sounds were normal. The abdomen was moderately distended with generalized tenderness but more marked at the lower abdomen. There was no palpable mass but percussion notes were hyperresonant and bowel sounds were reduced. The rectum was empty on rectal examination. Vaginal examination revealed a circumcised vulva and no obvious vaginal discharge. The cervix was central and the anterior lip had some marks of instrumentation. The cervical os was closed. There was positive cervical excitation tenderness. The uterine size could not be assessed, as patient was uncooperative because of the lower abdominal tenderness.

An initial assessment of uterine perforation with bowel injuries following unsafe abortion was made and patient was admitted for investigations and management. She was commenced on intravenous antibiotics (ampiclox, genticin and flagyl) and infusion of dextrose/saline. A general surgeon also reviewed her. Her haemoglobin came out to be 9.6gldl and urinalysis showed no abnormality. Ultrasound findings were not contributory and plain abdominal X - rays (erect and supine) were inconclusive. Chest $\mathrm{X}$ - ray did not reveal any gas under the diaphragm. Requests were also made for endocervical and high vaginal swabs for microscopy and culture as well as the renal function tests. The renal function was normal and swabs yielded growth of coliforms, sensitive to antibiotics already in use.

A nasogastric tube was passed and kept insitu. Patient was eventually scheduled for exploratory laparotomy by a combined team of surgeons and gynaecologists. Intraoperative findings included: normal sized uterus with no obvious injury, distended loops of small intestine, band of adhesion binding down a segment of the ileum, about $3 \mathrm{~cm}$ from the caecum (band was from the appendicetomy site), no injuries were noticed in other visceral organs. Release of the adhesion band was done and the distended 
proximal bowel loop was decompressed by milking it backwards into the stomach to drain out via the nasogastric tube.

Patient made an uneventful recovery and was discharged on the $9^{\text {th }}$ postoperative day. When seen six weeks later, she was cheerful and had no complaints. She was then referred to the family planning clinic for contraceptive advice.

\section{Discussion}

Intestinal obstruction is one of the common and potentially fatal complications following previous surgery. Adhesions, usually secondary to previous surgical procedure, have been shown to be the most common cause of intestinal obstruction and are responsible for $49-74 \%$ of small bowel obstruction in developed countries ${ }^{3}$. In Nnewi, Eastern Nigeria, 29\% of intestinal obstruction in adult was due to adhesions from previous surgeries. ${ }^{4}$ Gynaecological procedures, appendicectomies (as in the case presented) and other intestinal surgeries are the three most common types of surgical procedures performed before the occurrence of these observed substantial peritoneal adhesions ${ }^{5}$.

Obstruction of the small intestine leads to accumulation of intestinal secretions and swallowed air, which further distends the loops of bowel and hence the abdomen. With further distention, the accumulated fluids in the intestine with its bacterial contamination seep through some areas of necrosis into the body system thereby making the patient more toxic ${ }^{2}$.

The clinical presentation of this patient shared the same characteristic features of septic abortion with injury to visceral organs, and this tilted the diagnosis in that direction. The management of small bowel intestinal obstruction due to postoperative adhesions differs slightly. Some workers had achieved high success rate by simple gastrointestinal intubation of the patient ${ }^{6-8}$. Carey and Fabri (1992) ${ }^{9}$ recommended that patients that should be managed conservatively are those who had been operated on severally and are known to have dense intestinal adhesions, those with known widespread intra-abdominal malignancy and those who develop obstruction in the early post-operative period. But it is recommended generally that initial approach to the management of intestinal obstruction from adhesions and bands from previous abdominal surgery is conservative with correction of fluid and electrolyte imbalance and decompression of the distended loops of intestine. ${ }^{6}$ Where conservative management fails, surgery must be employed to save the life of the patient. The quick operative intervention in this patient was necessitated by the history of induced abortion with possible damage to visceral organs.

In conclusion, adhesions and bands formation after surgery are great causes of morbidity and mortality. This case highlights the similarities of its presentation to some of the complications of induced unsafe abortion. It also highlights the need for careful and detailed evaluation of every clinical history on its own merit, and Surgeons should always be mindful of the effects of previous surgeries in making their diagnosis even in the face of seemingly obvious diagnosis.

\section{REFERENCES}

1. Kerr Wilson. Injury to Bowel during gynaecological surgery. In: Studd J (ed) Progress in Obstetrics and Gynaecology 1990; 8: 219- 231.

2. El-Mowafi D, Diamond M. Adhesions and Intestinal obstruction after gynaecological surgery. In: Studd J (ed) Progress in Obstetrics and Gynaecology 2000; 14 : 413-428.

3. Welch JP. Adhesions. In Welch JP (ed) Bowel obstructions. W B Saunders, Philadelphia 1990; 154-165.

4. Osuigwe AN, Anyanwu SNC. Acute Intestinal Obstruction in Nnewi, Nigeria, a five-year review. Nigerian Journal of Surgical Research 2002, 4(3): 107111.

5. Ulvic NM, Qvigstad E. Mechanical small bowel obstruction due to adhesions. Annals of Clinical Gynaecology 1978; 62: 13-16.

African Journal of Reproductive Health Vol. 11 No.2 Angust 2007 
6. Krebs HE, Goplerud DR. Mechanical intestinal Obstructions in patients with gynaecologic disease: a review of 368 patients. AM J Obstet gynaecol 1987; $157: 577-583$.

7. Helmkamp BF, Kimmel J. Conservative management of small bowel obstruction. AM J Obstet Gynaecol 1985: 152: 677-682.
8. Peetz DJ, Gamelli RL, Pitcher DB. Intestinal intubation in acute mechanical bowel obstruction. Arch. Surg 1982; 117: 334-339.

9. Carey JC, Fabri PJ. The intestinal tract in relation to Gynaecology. In: Thompson JD, Rock JA(eds) Operative Gynaecology. JB Lippencott, Philadelphia 1992; 1017-1047. 